\title{
The Effect of Job Autonomy on Turnover Intention: Mediation Role of Work-Life Balance, and Job Satisfaction in the Banking Sector
}

\author{
Khusnul Rofida Novianti ${ }^{*}$, Iqbal Ramadhani Fuadiputra ${ }^{2}$ \\ 1,2 Management Department, Universitas Muhammadiyah Malang, Malang, Indonesia
}

\section{ART ICLE INFO}

\section{Article history:}

Received August 20, 2021

Revised August 23, 2021

Accepted October 23, 2021

Available online November 25, 2021

Keywords:

Covid-19 Pandemic, HR Practice, Hospitality, Survival Strategy, Entrepreneurship

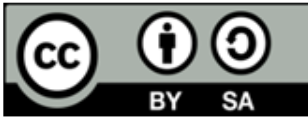

This is an open access article under the CC BY-SA license.

Copyright $(2021$ by Author. Published by Universitas Pendidikan Ganesha.

\begin{abstract}
A B S T R A C T
The banking sector is one of the sectors driving the Indonesian economy whose contribution is above. Banking activities are engaged in managing financial and non-financial products that are known to have a high employee turnover rate. The high level of employee turnover is influenced by various things, including work autonomy, work-life balance, and job satisfaction. For this reason, this study aims to examine the effect of work autonomy, worklife balance, and job satisfaction on turnover intention in the banking sector of Malang City. This study uses a quantitative approach with online questionnaire data collection. Data was collected by distributing questionnaires (online and offline) using a Likert scale ranging from 1-5. The population in this study were employees in the banking sector. The sample in this study uses a non-probability method with a sample size of 100. Data analysis uses Smart PLS (Partial Least Square) to describe the relationship between variables. The Sobel test was used to analyze the effect of the mediating variables, namely work-life balance and job satisfaction. The results showed that work autonomy significantly affected job satisfaction, work-life balance, and turnover intention. Work-life balance also has a significant effect on turnover intention. However, job satisfaction has no significant effect on turnover intention. In terms of mediating effects, worklife balance can mediate the effect of job autonomy on turnover intention. Meanwhile, job satisfaction has no mediating effect between work autonomy and turnover intention.
\end{abstract}

\section{INTRODUCTION}

Since the early 1990s, work-life balance and job satisfaction have been regularly employed as a predictor of job and life happiness. The majority of studies look at the direct and indirect effects of worklife balance (such as autonomy and work-life conflicts) on job satisfaction (Grolleau et al., 2022; MasMachuca et al., 2016). Several work-life balance studies focus on women or female professionals who have several roles (Dickson et al., 2021; Y. Fan \& Potočnik, 2021). The development of technology and the times in the current era continue to develop in society (Astuti et al., 2021; Kaplan et al., 2021). This also applies to the change of generations in the world of work today, there are two generations with different characters who are involved in the world of work. Generations X and Y are distinguished by the range of the year they were born, Gen X who is filling the world of work today are employees who are over 35 years old (Bento et al., 2018; Lissitsa \& Laor, 2021). Meanwhile, Gen Y who now dominates the world of work are employees in the 21-35 year age range. Each generation category has its character, Gen X tends to work to achieve stability and independence in terms of economy and career, Gen Y who grows up with technology is better known as a generation that is thirsty for new challenges, curious, dynamic, and works to optimize potential they have. Millennials, often known as generation Y, are a group of people who are currently employed (Betz, 2019; Dhanapal et al., 2015). Millennials will select fascinating employment, achieve strong achievements, and have prospects for career advancement. The features of the creative millennial generation include a focus on work-life balance. Work-life balance is a state of equilibrium between one's work or career and one's personal life (pleasure, leisure, family development, and spiritual) (Y. Fan \& Potočnik, 2021; Wei \& Villwock, 2021).

In comparison to earlier generations, the Millennial generation values a better work-life balance (Gabrielova \& Buchko, 2021; Majmundar et al., 2021). Millennials are more likely to work flexibly or not at

*Corresponding author.

E-mail: khusnulrofida@umm.ac.id 
all, to strike a balance between work and life (Cirillo et al., 2021; Tang et al., 2020). Studies related to the concept of individual and organizational outcomes have become an interesting discussion in the last few years, especially in the pandemic situation in the past year. The level of employee turnover intention in an organization becomes an important issue to be followed up immediately for organizational decisionmakers. The high turnover rate is a negative indication for an organization that many things are happening, generally related to personal factors, the environment, or even the organization itself. The main factor that causes a person to leave his job is often related to job satisfaction issues, which include the separation between personal and work life (work-life balance) as well as flexibility and work independence (job autonomy). Job autonomy creates jobs that provide employees a lot of freedom in how they carry out their responsibilities (Charoensukmongkol, 2022; Sang et al., 2021). Increased autonomy will allow people to be more flexible in their work, and it will also allow them to be more innovative. Work autonomy has been found to have a good impact on work-life balance (Fisher et al., 2009; Mas-Machuca et al., 2016). Job satisfaction is defined as the extent to which employees feel satisfaction or a sense of accomplishment obtained from their work. It is the cause of a person to achieve their work values or meet their basic needs through assessment.

Work-life balance is the concept of achieving satisfying experiences in all life domains and requiring personal resources such as energy, time, and commitment to be well distributed across domains. The imbalance in this regard can take any form when work extends to the family realm or family problems extend to the work realm, this can be a potential cause of stress and non-constructive work attitudes for employees, which is positively related to burnout (Dickson et al., 2021; Tziner et al., 2015). Organizations that adhere to the work-life balance concept are favored by potential employees and they will also gain a reputation as the employer of choice (Inegbedion et al., 2020; Sergeeva \& Kortantamer, 2021). The inconsistency of research results related to job autonomy, work-life balance, job satisfaction, and turnover intention is an interesting thing to study further, especially during the Covid-19 pandemic in the banking sector which is synonymous with high turnover rates. This study discusses related to job autonomy which has an understanding of the extent to which work can provide great freedom, independence, and individual wisdom in scheduling work and determining the procedures to be used in implementing the work that is being carried out and carried out (Johari et al., 2016; Sang et al., 2021). Some studies also mention that autonomy leads to a critical psychological state in which a person can be responsible for the results of the work he does, which in turn leads to results, such as better work efficiency and higher levels of internal work motivation. It can be said that this factor is considered to result in increased motivation and work effectiveness.

Job satisfaction can be defined as a person's feelings towards his job. Job satisfaction will appear in the positive attitude of employees towards work and everything that is faced in the work environment. As a collection of feelings, job satisfaction is dynamic (Davidescu et al., 2020; Yuliandi \& Tahir, 2019). Job satisfaction has experienced ups and downs, thus requiring leaders to pay attention to employee satisfaction at all times (Hanna et al., 2017; Katsantonis, 2019). Job satisfaction has two main parts, namely an affective component and a non-affective component. The affective component refers to the emotional state of the employee, while the non-affective (cognitive) component refers to the satisfaction associated with performance appraisal. Job satisfaction is an important factor that needs to be considered by the management because it greatly affects the organization both directly and indirectly. Several researchers have confirmed the relationship between job satisfaction and turnover intention (Cegarra-Leiva et al., 2012; Chen et al., 1999). Poor job satisfaction will arise when workers begin to feel that unwanted financial, emotional, and intellectual aspects will have an impact on their work which is indicated by frequent absenteeism and substandard work (Holtom et al., 2008; Mihelic \& Tekavcic, 2013).

Work-Life Balance (WLB) has the meaning of a harmonious balance between various areas of life (Abendroth \& den Dulk, 2011; Badri, 2019). The WLB concept is built on the idea that work life and personal life are interrelated with each other and need to be run together in one's life. Success in achieving a worklife balance can bring many benefits to employers because employees are more motivated, productive, and feel less work stress (Abendroth \& den Dulk, 2011; Mas-Machuca et al., 2016). Lack of attention to WLB will inhibit employee motivation which causes them to show it by withdrawing from the organization (turnover) (Cegarra-Leiva et al., 2012; Fuadiputra \& Novianti, 2021). The more conflicts that arise between work and personal life, the more employees or individuals will struggle to maintain a balance and eventually quit their jobs. In the end, this will be very detrimental to the organization because the resources that have been given make a turnover.

Turnover intention is the possibility of an employee leaving the organization (Lotfi et al., 2022; Ma et al., 2020). Researchers measure the desire to do turnover itself using time intervals and opportunities as a person's choice to leave the company. Some researchers have also noted several factors that might contribute to the increased consideration of individuals leaving the organization. One of the things that 
encourage someone to do turnover intention is someone's desire to look for new challenges or the worker just wants to quit the routine is used to. If the characteristics of work or job autonomy do not achieve job satisfaction for employees, it will have a positive impact on increasing absenteeism and turnover. But if on the contrary, when employees are satisfied, it will reduce the employee's desire for absenteeism and turnover. For this reason, this study aims to examine the effect of job autonomy, work-life balance, and job satisfaction on turnover intention in the Malang City banking sector.

\section{METHODS}

Using a quantitative approach, this research tries to describe the relationship between variables tested that is job autonomy, work-life balance, and job satisfaction on turnover intention in the banking sector. Data was collected by distributing questionnaires (online and offline) using a Likert scale ranging from 1-5. The population in this study were employees in the banking sector in Malang City. The determination of the sample in this study used a non-probability method because the population size could not be identified (Cooper \& Schindler, 2014). Determination of the minimum sample size with the variable 5 , the number of samples is 100 , while for the variable 7 the minimum is 150 , and the variable 7 is 300 . Job autonomy is measured using 15 items in the Nordic QPS questionnaire, work-life balance is measured using 10 items proposed by (Hayman, 2005). Job satisfaction adapted from (Lee \& Bruvold, 2003) and turnover intention is measured using 3 items adapted from (Rizwan, 2014) so the total items are 31 items. Data analysis uses Smart PLS (Partial Least Square) to describe the relationship between variables using the outer model, inner model, and hypothesis testing. The Sobel test was used to determine the effect of the mediating variables, namely work-life balance, and job satisfaction.

\section{RESULTS AND DISCUSSIONS}

\section{Results}

Based on table 1, the description of the respondents obtained is that $60 \%$ are women who are respondents in this study. In addition, it can be seen from the table that $52 \%$ are married and the rest are single. They are 36 to 40 years old, and most of the work between 3-4 years. The majority of respondents are university graduates $80 \%$. The demographics of respondents can be seen in Table 1 .

Table 1. Demographics of Respondents

\begin{tabular}{|c|c|c|c|}
\hline Detail & Item & $\begin{array}{c}\text { Frequency } \\
(N=100)\end{array}$ & $\begin{array}{c}\text { Percentage } \\
\%\end{array}$ \\
\hline \multirow[t]{2}{*}{ Gender } & Female & 60 & 60 \\
\hline & Male & 40 & 40 \\
\hline \multirow[t]{6}{*}{ Age (years) } & $20-25$ & 22 & 22.3 \\
\hline & $26-30$ & 12 & 12.5 \\
\hline & $31-35$ & 20 & 20 \\
\hline & $36-40$ & 24 & 24.3 \\
\hline & $41-45$ & 12 & 12.5 \\
\hline & $>46$ & 10 & 8.4 \\
\hline \multirow{2}{*}{ Status } & Married & 52 & 52 \\
\hline & Single & 48 & 48 \\
\hline \multirow[t]{5}{*}{ Length of service } & $<1$ year & 9 & 9 \\
\hline & $1-2$ years & 24 & 24 \\
\hline & 3-4 years & 32 & 32 \\
\hline & $5-6$ years & 15 & 15 \\
\hline & $>6$ years & 20 & 20 \\
\hline \multirow[t]{4}{*}{ Education } & High school & 1 & 1 \\
\hline & Diploma & 5 & 5 \\
\hline & Bachelor & 80 & 80 \\
\hline & Magister & 14 & 14 \\
\hline
\end{tabular}

The findings of the external model evaluation are shown using convergent validity and unidimensionality. The ideal loading value is greater than 0.7 but loading values between 0.5 and 0.7 are acceptable (Hair et al., 2014). There were no variables with an outer loading of less than 0.5 in this study, indicating that there was no convergent validity issue. Composite reliability was used to assess unidimensionality. Each variable's composite reliability value must be greater than 0.7. Because the score was above 0.8 , there were no issues with unidimensionality. 
Table 2. External Load and Composite Reliability

\begin{tabular}{lccc}
\hline \multicolumn{1}{c}{ Variable } & AVE & $\sqrt{\text { AVE }}$ & Composite Reliability \\
\hline Job Autonomy & 0.5185 & 0.72 & 0.928 \\
Job Satisfaction & 0.6288 & 0.7929 & 0.949 \\
Work Life Balance & 0.5301 & 0.728 & 0.816 \\
Turnover Intention & 0.6873 & 0.829 & 0.9388 \\
\hline
\end{tabular}

The cross-loading value is compared to the outer loading score to verify discriminant validity. The external loading score must be higher than the cross-loading score. The outer loading of each variable is bigger than the cross-loading value, according to the PLS analysis. As a result, no discriminant validity concerns were found, as shown in Table 3.

Table 3. Summary of External Model Evaluation

\begin{tabular}{lcccc}
\hline \multicolumn{1}{c}{ Variable } & JA & WL & WLB & JS \\
\hline Job Autonomy (JA) & 1 & & & \\
Job Satisfaction (JS) & 0.6871 & 1 & & \\
Work Life Balance (WLB) & 0.661 & 0.6181 & 1 & 1 \\
Turnover Intention (TI) & 0.3174 & 0.4274 & 0.2785 & 1 \\
\hline
\end{tabular}

The coefficient of determination score is used to evaluate the inner model (R square). R2 values were divided into three categories: minor (0.25), moderate (0.50), and significant (0.75) (Hair et al, 1998). The value of $\mathrm{R}$ square is regarded as moderate in this investigation.

Table 4. Evaluation of Inner Model

\begin{tabular}{cc}
\hline Variable & R Square \\
\hline Job Autonomy (JA) & 0 \\
Job Satisfaction (JS) & 0.4721 \\
Work-Life Balance (WLB) & 0.437 \\
Turnover Intention (TI) & 0.1837 \\
\hline
\end{tabular}

Table 5. Hypothesis Test for Direct Effect Research

\begin{tabular}{ccccc}
\hline Variable & T-Stat & $\begin{array}{c}\text { Original } \\
\text { sample (0) }\end{array}$ & P Values & Result \\
\hline JA $\rightarrow$ JS & 9.409 & 0.661 & 0.000 & Significant \\
$\mathrm{JA} \rightarrow$ TI & 2.245 & 0.317 & 0.025 & Significant \\
$\mathrm{JA} \rightarrow$ WLB & 9.146 & 0.687 & 0.000 & Significant \\
$\mathrm{JS} \rightarrow$ TI & 0.048 & 0.007 & 0.962 & Not significant \\
WLB $\rightarrow$ TI & 2.514 & 0.394 & 0.012 & significant \\
\hline
\end{tabular}

In this investigation, seven hypotheses were offered. The hypothesis testing of each variable's direct effect is summarized in Table 5. Work-life balance is significantly influenced by job autonomy. Autonomy has a huge impact on work-life balance as well (H2). Other hypotheses (H3 and H4) have an impact on turnover intention. There is only one non-significant hypothesis (H5), namely the effect of work satisfaction on turnover intention, which the results do not support. Work autonomy has an indirect effect on turnover intention, which is mediated by work-life balance and job satisfaction, as shown in Table 6 . Work-life balance is predicted to have a mediating influence on the relationship between work autonomy and turnover intention in Hypothesis 6. The mediation effect of work satisfaction on the connection between job autonomy and turnover intention is predicted by Hypothesis 7. It can be described in the table below, based on the findings of hypothesis testing.

Table 6. Hypothesis Test for Mediating Effect

\begin{tabular}{ccccc}
\hline Variable & T-Stat & $\begin{array}{c}\text { Original } \\
\text { sample (0) }\end{array}$ & P-value & Result \\
\hline $\mathrm{JA} \rightarrow \mathrm{JS} \rightarrow \mathrm{TI}$ & 0.047 & 0.005 & 0.962 & Not significant \\
\hline $\mathrm{JA} \rightarrow \mathrm{WLB} \rightarrow \mathrm{TI}$ & 2.406 & 0.271 & 0.016 & significant \\
\hline
\end{tabular}




\section{Discussion}

The results of the research above show that job autonomy has a positive and significant relationship with the desire to move, which is mediated by work-life balance, which is supported by the results show the results that work autonomy and work-life balance have a significant effect on the desire to move (Abdien, 2019; Abendroth \& den Dulk, 2011; Mas-Machuca et al., 2016). Job autonomy itself has a meaning that with work autonomy, it is expected that workers will be able to complete work (Saragih, 2011; Sisodia \& Das, 2013).The intention of turnover in the banking sector has an impact. The more the autonomy of the work made, the more limited the balance of life that he has also had an effect. Someone as an individual feels this is an attempt to get out of someone's current job. This study also measures supports research that the impact generated when job autonomy can affect the backlash with some research findings this is also evident in the banking sector, which is supported by job autonomy. make their job satisfaction does not affect their desire to leave (Liu \& Lo, 2018). This is due to the limited job autonomy provided by the banking profession, which encourages a person to be dissatisfied.

According to the findings of the research, job autonomy has a considerable impact on work-life balance and supported the prior research by (Fuadiputra \& Novianti, 2021; Johari et al., 2016; Valcour, 2007; Valcour \& Hunter, 2017). This conclusion is influenced by the level of work autonomy provided, which has a substantial impact since the larger the sense of responsibility to complete the task, the stronger the sense of duty to complete the task, and ultimately the impact on work balance (Fuadiputra \& Novianti, 2021; Sisodia \& Das, 2013). Work-life balance will also influence overall performance and success. These findings are based on the work authorization granted to both male and female employees, which encourages them to perform at their best, which has an impact on how they complete work, particularly in the banking industry, which demands experience to complete work well. The above study's findings are also consistent with those found that work autonomy improves work-life balance (Chawla \& Sondhi, 2011; J. Fan \& Smith, 2017). Work autonomy inevitably raises the level of job satisfaction among bank employees. This study also suggests that managing a decent workload will result in a work-life balance. The more the workload, the worse the work-life balance becomes, or it may even make them feel more challenged and as if this is an advantage. The findings of the above study are also consistent with those found that work autonomy improves work-life balance Work autonomy inevitably raises the level of job satisfaction among bank employees. This study also suggests that managing a decent workload will result in a work-life balance. The more the workload, the worse the work-life balance becomes, or it may even make them feel more challenged and as if this is an advantage.

Furthermore, when banking staff is in middle management and senior management positions, their authority grows significantly. Workers in this position are thought to be of higher quality when it comes to completing duties. These findings highlight the need of focusing on aspects of work-life balance and job satisfaction that need to be improved, particularly among bank employees. When using work satisfaction mediation, the data gathered based on the findings of the previous study likewise shows that job autonomy has no significant impact on turnover intention. When job autonomy is linked to job happiness, however, it still has an impact. This is corroborated by research, which found no link between work satisfaction and turnover intention, and that the association is negative (Badri, 2019). This is because when someone is satisfied, they do not feel compelled to leave did research that backs this up (Vui-Yee \& Yen-Hwa, 2020). The study contains limitations, such as the small number of samples and the fact that it only included personnel in Malang's banking sector. This concept could be replicated in other sectors such as industry, education, tourism, the private sector, and government in the future. We propose that future research include numerous dependent variables such as ostracism, quality of work-life, work conflict, job performance, and welfare. Moderating variables utilized in further study, such as work atmosphere or variables connected to the work environment, can also be introduced.

\section{CONCLUSION}

The findings of this study show that work authority has no bearing on the likelihood of turnover. This is because when someone is content with their employment, they tend to feel more at ease with the authority that has been handed to them. These findings can help leaders make better decisions. When work authority is coupled with job pleasure, a person can be encouraged to stay at his job by providing a pleasant environment and incentives that are appropriate for his workload. It can be observed from one of the hypotheses, which suggests that giving a great job power produces a sense of responsibility in every person, allowing them to share it with life outside the workplace, which does not affect workers' desire to quit the banking industryt. 


\section{REFERENCES}

Abdien, M. (2019). Impact of communication satisfaction and work-life balance on employee turnover intention. Journal of Tourism Theory and Research, 5(2), 228-238. https://doi.org/10.24288/jttr.526678.

Abendroth, A. K., \& den Dulk, L. (2011). Support for the work-life balance in europe: The impact of state, workplace and family support on work-life balance satisfaction. Work, Employment and Society, 25(2), 234-256. https://doi.org/10.1177/0950017011398892.

Astuti, M., Arifin, Z., Mutohhari, F., \& Nurtanto, M. (2021). Competency of Digital Technology: The Maturity Levels of Teachers and Students in Vocational Education in Indonesia. Journal of Education Technology, 5(2), 254-262. https://doi.org/10.23887/jet.v5i3.35108.

Badri, S. K. Z. (2019). Affective well-being in the higher education sector: connecting work-life balance with mental health, job satisfaction and turnover intention issues inside the academia setting. International Journal of Happiness and Development, 5(3), 225. https://doi.org/10.1504/ijhd.2019.103382.

Bento, M., Martinez, L. M., \& Martinez, L. F. (2018). Brand engagement and search for brands on social media: Comparing Generations $\mathrm{X}$ and $\mathrm{Y}$ in Portugal. Journal of Retailing and Consumer Services, 43. https://doi.org/10.1016/j.jretconser.2018.04.003.

Betz, C. L. (2019). Generations X, Y, and Z. Journal of Pediatric Nursing, 44. https://doi.org/10.1016/j.pedn.2018.12.013.

Cegarra-Leiva, D., Eugenia Sánchez-Vidal, M., \& Cegarra-Navarro, J. G. (2012). Understanding the link between work life balance practices and organisational outcomes in SMEs: The mediating effect of a supportive culture. Personnel Review, 41(3), 359-379. https://doi.org/10.1108/00483481211212986.

Charoensukmongkol, P. (2022). Supervisor-subordinate guanxi and emotional exhaustion: The moderating effect of supervisor job autonomy and workload levels in organizations. Asia Pacific Management Review, 27(1). https://doi.org/10.1016/j.apmrv.2021.05.001.

Chawla, D., \& Sondhi, N. (2011). Assessing work-life balance among Indian women professionals. The Indian Journal of Industrial Relations, 47(2), 341-352.

Chen, G., Ployhart, R. E., Thomas, H. C., Anderson, N., \& Bliese, P. D. (1999). The Power of Momentum: A New Model of Dynamic Relationship Between Job Satisfaction Change and Turnover Intentions. Academy of Management Journal, 54(1982), 159-181.

Cirillo, A., Maggi, B., Sciascia, S., Lazzarotti, V., \& Visconti, F. (2021). Exploring family millennials' involvement in family business internationalization: Who should be their leader? Journal of Family Business Strategy. https://doi.org/10.1016/j.jfbs.2021.100455.

Cooper, D. ., \& Schindler, P. . (2014). Business Research Methods. McGraw-Hill.

Davidescu, A. A., Apostu, S.-A., Paul, A., \& Casuneanu, I. (2020). Work Flexibility, Job Satisfaction, and Job Performance among Romanian Employees-Implications for Sustainable Human Resource Management. Sustainability, 12(15), 6086. https://doi.org/10.3390/su12156086.

Dhanapal, S., Vashu, D., \& Subramaniam, T. (2015). Perceptions on the challenges of online purchasing: a study from "baby boomers", generation "X" and generation " $\mathrm{Y}$ " point of views. Contaduría $y$ Administración, 60(1). https://doi.org/10.1016/j.cya.2015.08.003.

Dickson, V. V., Jun, J., \& Melkus, G. D. (2021). A mixed methods study describing the self-care practices in an older working population with cardiovascular disease (CVD): Balancing work, life and health. Heart \& Lung, 50(3). https://doi.org/10.1016/j.hrtlng.2021.02.001.

Fan, J., \& Smith, A. P. (2017). Mental Workload: Assessment, Prediction and Consequences. Communications in Computer and Information Science, 726, 18-29. https://doi.org/10.1007/978-3-319-61061-0.

Fan, Y., \& Potočnik, K. (2021). The impact of the depletion, accumulation, and investment of personal resources on work-life balance satisfaction and job retention: A longitudinal study on working mothers. Journal of Vocational Behavior, 131. https://doi.org/10.1016/j.jvb.2021.103656.

Fisher, G. G., Bulger, C. A., \& Smith, C. S. (2009). Beyond Work and Family: A Measure of Work/Nonwork Interference and Enhancement. Journal of Occupational Health Psychology, 14(4), 441-456. https://doi.org/10.1037/a0016737.

Fuadiputra, I. R., \& Novianti, K. R. (2021). The Effect of Work Autonomy and Workload on Job Satisfaction of Female Workers in the Banking Sector: Mediating the Role of Work Life Balance. The Winners, 21(2), 85-91. https://doi.org/10.21512/tw.v21i2.6908.

Gabrielova, K., \& Buchko, A. A. (2021). Here comes Generation Z: Millennials as managers. Business Horizons, 64(4). https://doi.org/10.1016/j.bushor.2021.02.013.

Grolleau, G., Mzoughi, N., \& Pekovic, S. (2022). An empirical analysis of the relationship between innovation activities and job satisfaction among French firms. Journal of Vocational Behavior, 133. 
https://doi.org/10.1016/j.jvb.2021.103689.

Hair, J. F., Black, W. C., Babin, B. J., \& E., A. R. (2014). Multivariate Data Analysis (7th Edition). Pearson Education Limited.

Hanna, B., Kee, K. F., \& Robertson, B. W. (2017). Positive Impacts of Social Media at Work: Job Satisfaction, Job Calling, and Facebook Use among Co-Workers. SHS Web of Conferences, 33(SHS Web Conf), 00012. https://doi.org/10.1051/shsconf/20173300012.

Hayman, J. (2005). Psychometric Assessment of an Instrument Designed to Measure Work Life Balance. Research and Practice in Human Resource Management, 13(1), 85-91.

Holtom, B. C., Mitchell, T. R., Lee, T. W., \& Eberly, M. B. (2008). Turnover and Retention Research: A Glance at the Past, a Closer Review of the Present, and a Venture into the Future. The Academy of Management Annals, 2(1), 231-274. https: //doi.org/10.1080/19416520802211552.

Inegbedion, H., Inegbedion, E., Peter, A., \& Harry, L. (2020). Perception of workload balance and employee job satisfaction in work organisations. Heliyon, 6(1). https://doi.org/10.1016/j.heliyon.2020.e03160.

Johari, J., Tan, fee Y., \& Tjik, Z. I. (2016). Autonomy, workload, worklife balance and job performance teachers. International Journal for Researcher Development, 7(1), 63-83. https://doi.org/http://dx.doi.org/10.1108/MRR-09-2015-0216.

Kaplan, L. R., Farooque, M., Sarewitz, D., \& Tomblin, D. (2021). Designing Participatory Technology Assessments: A Reflexive Method for Advancing the Public Role in Science Policy Decision-making. Technological Forecasting and 171. https://doi.org/10.1016/j.techfore.2021.120974.

Katsantonis, I. G. (2019). Investigation of the impact of school climate and teachers' self-efficacy on job satisfaction: A cross-cultural approach. European Journal of Investigation in Health, Psychology and Education, 10(1), 119-133. https://doi.org/10.3390/ejihpe10010011.

Lee, C. H., \& Bruvold, N. T. (2003). Creating value for employees: Investment in employee development. International Journal of Human Resource Management, 14(6), 981-1000. https://doi.org/10.1080/0958519032000106173.

Lissitsa, S., \& Laor, T. (2021). Baby Boomers, Generation X and Generation Y: Identifying generational differences in effects of personality traits in on-demand radio use. Technology in Society, 64. https://doi.org/10.1016/j.techsoc.2021.101526.

Liu, H. L., \& Lo, V. hwei. (2018). An integrated model of workload, autonomy, burnout, job satisfaction, and turnover intention among Taiwanese reporters. Asian Journal of Communication, 28(2), 153-169. https: //doi.org/10.1080/01292986.2017.1382544.

Lotfi, M., Akhuleh, O. Z., Judi, A., \& Khodayari, M. (2022). Turnover intention among operating room nurses during the COVID-19 outbreak and its association with perceived safety climate. Perioperative Care and Operating Room Management, 26. https://doi.org/10.1016/j.pcorm.2021.100233.

Ma, Y., Chen, F., Xing, D., Meng, Q., \& Zhang, Y. (2020). Study on the associated factors of turnover intention among emergency nurses in China and the relationship between major factors. International Emergency Nursing, 22. https://doi.org/10.1016/j.ienj.2021.101106.

Majmundar, N., Graffeo, C. S., \& Johnson, J. N. (2021). Generation Why: Neurosurgery and the Millennial Moment. World Neurosurgery, 149. https://doi.org/10.1016/j.wneu.2021.02.070.

Mas-Machuca, M., Berbegal-Mirabent, J., \& Alegre, I. (2016). Work-life balance and its relationship with organizational pride and job satisfaction. Journal of Managerial Psychology, 31(2), 586-602. https://doi.org/10.1108/JMP-09-2014-0272.

Mihelic, K. K., \& Tekavcic, M. (2013). Work-Family Conflict: A Review Of Antecedents And Outcomes. International Journal of Management \& Information Systems (IJMIS), 18(1), 15-26. https://doi.org/10.19030/ijmis.v18i1.8335.

Rizwan, M. (2014). Determinants of Employees intention to leave. Dterminants of Employees Intention to Leave, 4(3), 1-19.

Sang, L., Liu, S., Keeley, J. W., Sui, Y., \& Sang, L. (2021). Impact of distributed leadership on teacher job satisfaction in China: The mediating roles of teacher autonomy and teacher collaboration. Studies in Educational Evaluation, 71. https://doi.org/10.1016/j.stueduc.2021.101099.

Saragih, S. (2011). The Effects of Job Autonomy on Work Outcomes: Self Efficacy as an Intervening Variable. International Research Journal of Business Studies, 4(3), 203-215. https://doi.org/10.21632/irjbs.4.3.203-215.

Sergeeva, N., \& Kortantamer, D. (2021). Enriching the concept of authentic leadership in project-based organisations through the lens of life-stories and self-identities. International Journal of Project Management, 39(7). https://doi.org/10.1016/j.ijproman.2021.09.001.

Sisodia, S., \& Das, I. (2013). Effect of Job Autonomy Upon Organizational Commitment of Employees at 
Different Hierarchical Level. Psychological Thought, 6(2), 241-251. https://doi.org/10.5964/psyct.v6i2.65.

Tang, S. Y. F., Wong, A. K. Y., Li, D. D. Y., \& Cheng, M. M. H. (2020). Millennial generation preservice teachers' intrinsic motivation to become a teacher, professional learning and professional competence. Teaching and Teacher Education, 96. https://doi.org/10.1016/j.tate.2020.103180.

Tziner, A., Rabenu, E., Radomski, R., \& Belkin, A. (2015). Work stress and turnover intentions among hospital physicians: The mediating role of burnout and work satisfaction. Revista de Psicologia Del Trabajo y de Las Organizaciones, 31(3), 207-213. https://doi.org/10.1016/j.rpto.2015.05.001.

Valcour, M. (2007). Work-Based Resources as Moderators of the Relationship Between Work Hours and Satisfaction With Work-Family Balance. Journal of Applied Psychology, 92(6), 1512-1523. https://doi.org/10.1037/0021-9010.92.6.1512.

Valcour, P.., \& Hunter, L. W. (2017). Technology, Organizations, and Work-Life Integration. In Work and Life Integration: Organizational, Cultural, and Individual Perspectives (Issue January, pp. 61-84). Lawrence Erlbaum Associates.

Vui-Yee, K., \& Yen-Hwa, T. (2020). When does ostracism lead to turnover intention? The moderated mediation model of job stress and job autonomy. IIMB Management Review, 32(3), 238-248. https://doi.org/10.1016/j.iimb.2019.10.007.

Wei, J. L., \& Villwock, J. A. (2021). Balance Versus Integration: Work-Life Considerations. Otolaryngologic Clinics of North America, 54(4). https://doi.org/10.1016/j.otc.2021.05.007.

Yuliandi, \& Tahir, R. (2019). Work discipline, competence, empowerment, job satisfaction, and employee performance. International Journal of Recent Technology and Engineering, 8(3), 7209-7215. https://doi.org/10.35940/ijrte.C6221.098319. 